\title{
Spatial scale-dependent land-atmospheric methane exchanges in the northern high latitudes from 1993 to 2004
}

\author{
X. Zhu ${ }^{1}$, Q. Zhuang ${ }^{1,2}$, X. Lu ${ }^{3}$, and L. Song ${ }^{1,4,5}$ \\ ${ }^{1}$ Department of Earth, Atmospheric, and Planetary Sciences, Purdue University, West Lafayette, IN, 47907, USA \\ ${ }^{2}$ Department of Agronomy, Purdue University, West Lafayette, IN 47907, USA \\ ${ }^{3}$ The Ecosystems Center, Marine Biological Laboratory, Woods Hole, MA 02543, USA \\ ${ }^{4}$ Institute of Geographic Sciences and Natural Resources Research, Chinese Academy of Sciences, Beijing, 100101, China \\ ${ }^{5}$ Graduate University of the Chinese Academy of Sciences, Beijing, 100049, China
}

Correspondence to: X. Zhu (zhu123@purdue.edu)

Received: 19 July 2013 - Published in Biogeosciences Discuss.: 28 November 2013

Revised: 16 February 2014 - Accepted: 19 February 2014 - Published: 1 April 2014

\begin{abstract}
Effects of various spatial scales of water table dynamics on land-atmospheric methane $\left(\mathrm{CH}_{4}\right)$ exchanges have not yet been assessed for large regions. Here we used a coupled hydrology-biogeochemistry model to quantify daily $\mathrm{CH}_{4}$ exchanges over the pan-Arctic from 1993 to 2004 at two spatial scales of $100 \mathrm{~km}$ and $5 \mathrm{~km}$. The effects of sub-grid spatial variability of the water table depth (WTD) on $\mathrm{CH}_{4}$ emissions were examined with a TOPMODEL-based parameterization scheme for the northern high latitudes. We found that both WTD and $\mathrm{CH}_{4}$ emissions are better simulated at a $5 \mathrm{~km}$ spatial resolution. By considering the spatial heterogeneity of WTD, net regional $\mathrm{CH}_{4}$ emissions at a $5 \mathrm{~km}$ resolution are 38.1-55.4 $\mathrm{Tg} \mathrm{CH}_{4} \mathrm{yr}^{-1}$ from 1993 to 2004, which are on average $42 \%$ larger than those simulated at a $100 \mathrm{~km}$ resolution using a grid-cell-mean WTD scheme. The difference in annual $\mathrm{CH}_{4}$ emissions is attributed to the increased emitting area and enhanced flux density with finer resolution for WTD. Further, the inclusion of sub-grid WTD spatial heterogeneity also influences the inter-annual variability of $\mathrm{CH}_{4}$ emissions. Soil temperature plays an important role in the $100 \mathrm{~km}$ estimates, while the $5 \mathrm{~km}$ estimates are mainly influenced by WTD. This study suggests that previous macroscale biogeochemical models using a grid-cell-mean WTD scheme might have underestimated the regional $\mathrm{CH}_{4}$ emissions. The spatial scale-dependent effects of WTD should be considered in future quantification of regional $\mathrm{CH}_{4}$ emissions.
\end{abstract}

\section{Introduction}

The importance of natural methane $\left(\mathrm{CH}_{4}\right)$ emissions from terrestrial ecosystems in the northern high latitudes in greenhouse gas radiative forcing has drawn great attention in the past decades (e.g., Koven et al., 2011; Gao et al., 2013; Zhu et al., 2013a). The regional $\mathrm{CH}_{4}$ budget and its temporal dynamics have been widely studied using "top-down" (e.g., Chen and Prinn, 2006; Kim et al., 2011) and "bottom-up" (e.g., Walter et al., 2001; Glagolev et al., 2011; Zhu et al., 2013b) approaches. However, it is still a challenge to have an accurate quantification given the high spatial and temporal variability of $\mathrm{CH}_{4}$ emissions from this region (Solomon et al., 2007). Laboratory and field studies indicate that the dynamics of $\mathrm{CH}_{4}$ fluxes are mainly determined by variations in water table, temperature, $\mathrm{pH}$, and microbial substrate availability (Whalen and Reeburgh, 1996; MacDonald et al., 1998; Christensen et al., 2003; Wagner et al., 2005). As an effective "bottom-up" approach, process-based biogeochemical models are often used to study the effects of these environmental factors on $\mathrm{CH}_{4}$ fluxes by considering the effects of soil hydrological and thermal dynamics on $\mathrm{CH}_{4}$ production and consumption (e.g., Zhuang et al., 2004; Wania et al., 2010). Among these abiotic and biotic environmental controlling factors, the dynamics of the water table depth (WTD) is one of the most important factors found in field observation-based (e.g., Nykänen et al., 1998; Heikkinen et al., 2002) and model-based (e.g., Petrescu et al., 2008; Bohn and Lettenmaier, 2010; Zhu et al., 2013b) studies. 
Since the measurements of water tables are only available at a limited number of sites over the earth's surface, most process-based biogeochemical models, operated at large spatial resolutions (e.g., 0.5 degrees), simply treat WTD as spatially uniform within each grid cell (a grid-cell-mean WTD scheme), without considering the sub-grid spatial heterogeneity of the water table position (e.g., Walter et al., 2001; Zhuang et al., 2004, 2007). This simple representation of WTD may bias grid-cell-mean $\mathrm{CH}_{4}$ fluxes, and therefore regional $\mathrm{CH}_{4}$ emissions. A recent model experiment that focused on a single model grid cell $(100 \mathrm{~km})$ (Bohn and Lettenmaier, 2010) indicated that the model-estimated $\mathrm{CH}_{4}$ emissions (without considering the sub-grid spatial heterogeneity of water tables) were biased by factors ranging from 0.5 to 2 . Further, assuming different sub-grid spatial variability of WTD, simulated daily $\mathrm{CH}_{4}$ fluxes with a grid-cellmean WTD scheme were found to be biased low and high as the water table fell and rose, respectively. However, seasonal variability of WTD, which is greatly influenced by climate conditions, may obscure the impact of WTD on the bias of $\mathrm{CH}_{4}$ emissions at a longer timescale. To date, it is still not clear how annual $\mathrm{CH}_{4}$ budgets will be affected in both their direction and magnitude when the sub-grid spatial heterogeneity of WTD is taken into account.

To our knowledge, there is no such study on the effects of spatial scale-dependent WTD on $\mathrm{CH}_{4}$ dynamics at large scales. Here we use a coupled hydrology-biogeochemistry model framework, incorporating sub-grid spatial variations in the WTD, to assess $\mathrm{CH}_{4}$ emissions from pan-Arctic terrestrial ecosystems with three objectives: (1) to quantify panArctic land-atmospheric $\mathrm{CH}_{4}$ exchanges at a fine spatial resolution by considering sub-grid spatial variability of WTD; (2) to analyze the spatial and temporal dynamics of $\mathrm{CH}_{4}$ emissions; and (3) to examine the difference in the magnitude and temporal variability of $\mathrm{CH}_{4}$ emissions with and without considering sub-grid spatial variability of WTD.

\section{Methods}

\subsection{Overview}

A macro-scale hydrological model, the Variable Infiltration Capacity (VIC, Liang et al., 1994), and a biogeochemical model, the Terrestrial Ecosystem Model (TEM, Zhuang et al., 2004), were coupled (Fig. 1) to make estimates of daily $\mathrm{CH}_{4}$ exchanges between terrestrial ecosystems and the atmosphere over the pan-Arctic (Fig. 2a), which is defined as the land area within the watersheds of major rivers that drain into the Arctic Ocean, excluding ice-dominated Greenland and Iceland (Lammers et al., 2001). To consider the effects of sub-grid spatial variability of WTD on estimated $\mathrm{CH}_{4}$ emissions, the grid-cell-mean WTD simulated by VIC at a coarser spatial resolution was downscaled into a finer resolution at a sub-grid level using a TOPMODEL-based parameterization. The VIC-TEM-TOPMODEL framework was initially developed by Lu and Zhuang (2012) to estimate land-atmospheric $\mathrm{CH}_{4}$ exchanges in the Alaskan Yukon Basin. Here, the same coupled framework but with a new TOPMODEL-based parameterization scheme was used to assimilate satellite-based inundation data to improve the parameterization of TOPMODEL-based WTD redistribution.

\subsection{Models and data}

The TEM model explicitly simulates carbon and nitrogen dynamics of vegetation and soils, and has been used to examine terrestrial $\mathrm{CH}_{4}$ dynamics in the northern high latitudes (Zhuang et al., 2004; McGuire et al., 2010; Zhu et al., 2011). TEM has its hydrological module (Zhuang et al., 2002) to simulate water dynamics of terrestrial ecosystems. However, like many existing biogeochemistry models, such as Biome-BGC (Hunt and Running, 1992), GOTILWA+ (Gracia et al., 1999), and HyLand (Levy et al., 2004), the hydrological module is formulated as a simple "single-bucket" model. To improve the estimates of the soil moisture profile, a key controlling factor for biogeochemical processes of $\mathrm{CH}_{4}$, more sophisticated hydrological models, like VIC, are needed (e.g., Bohn and Lettenmaier, 2010; Lu and Zhuang, 2012). The VIC model used physically based formulations to calculate energy fluxes and soil water movement and runoff (Liang et al., 1994). The explicit representation of the frozen soil/permafrost algorithm (Cherkauer et al., 2003) improved the capacity of the VIC model for cold region studies ( $\mathrm{Su}$ et al., 2005, 2006). In the VIC-TEM-TOPMODEL framework (Fig. 1), the VIC model was first used to estimate daily moisture and energy balance. The simulated soil temperature profile, freeze/thaw fronts, and soil ice profile were directly fed into TEM, while the simulated soil moisture profile was converted into WTD based on the soil moisture deficit method (Bohn et al., 2007) and then fed into TEM after redistributing WTD based on a TOPMODEL parameterization scheme. Finally, TEM was run to simulate daily $\mathrm{CH}_{4}$ emissions and consumption over the pan-Arctic.

The process-based TEM model explicitly simulates $\mathrm{CH}_{4}$ production, oxidation, and transport (diffusion, ebullition, and plant-aided transport) processes in the soil, with the following governing equation (Zhuang et al., 2004):

$$
\begin{gathered}
\frac{\partial C_{M}}{\partial t}=\frac{\partial\left(D\left(\partial C_{M} / \partial z\right)\right)}{\partial z}+P-Q-E-R \\
\left(\max \left(0, Z_{\mathrm{wt}}\right) \leq z \leq Z_{\text {soil }}\right),
\end{gathered}
$$

where $C_{M}$ is soil $\mathrm{CH}_{4}$ concentration at a given depth ( $1 \mathrm{~cm}$ depth step) and a given time (1 h time step); $\partial\left(D\left(\partial C_{M} / \partial z\right)\right) / \partial z$ is $\mathrm{CH}_{4}$ diffusion and $D$ is the $\mathrm{CH}_{4}$ diffusivity in soil column; $P, Q, E$, and $R$ represent the $\mathrm{CH}_{4}$ production, oxidation, ebullition, and plant-aided transport rate, respectively; $Z_{\mathrm{wt}}$ is WTD and $Z_{\text {soil }}$ is the lower boundary of the soil column. These $\mathrm{CH}_{4}$-related processes were formulated as functions of climate, vegetation, and soil conditions 


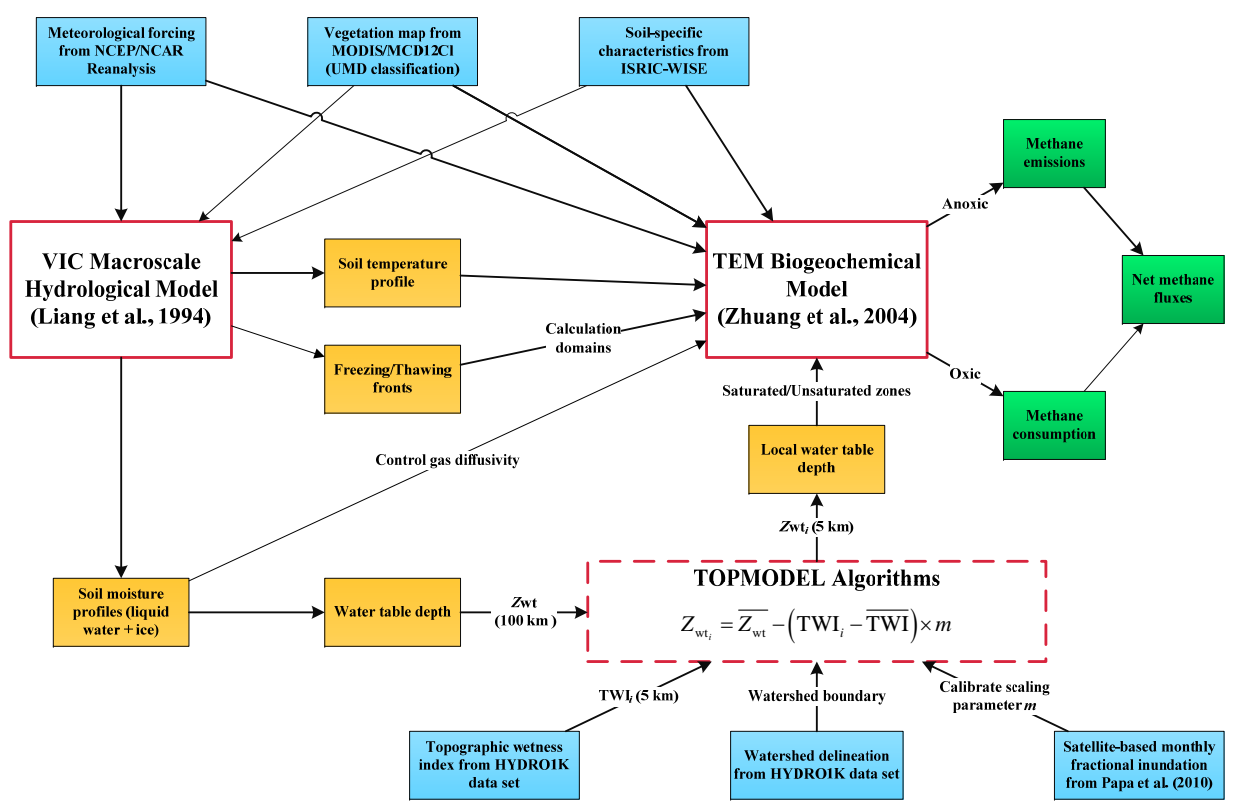

Fig. 1. Conceptual framework of coupled models to estimate net methane emissions. Shown are external spatial inputs (blue) for driving or calibrating models, internal information exchange (yellow) between models, and final model outputs (green). Arrows indicate the direction of information exchange among all components. See text and auxiliary materials for more details.

for major terrestrial ecosystems in the northern high latitudes (Zhuang et al., 2004).

To run the VIC and TEM models within the VICTEM-TOPMODEL framework, the spatial data of climate, vegetation, and soil from a variety of sources were used (Fig. 1). Gridded daily meteorological forcing data was acquired from NCEP/NCAR Reanalysis data sets (http://www.esrl.noaa.gov/psd/data/gridded/data. ncep.reanalysis.surfaceflux.html). For VIC, precipitation, maximum/minimum air temperature and wind speed were used. For TEM, precipitation, mean air temperature and downward shortwave solar radiation were required, except for those forcing from VIC simulations (soil temperature/moisture profiles and freezing/thawing fronts). For both VIC and TEM, gridded vegetation-type information was derived from MODIS/MCD12C1 products with a UMD vegetation classification scheme (https://lpdaac.usgs.gov/products/ modis_products_table/mcd12c1), and gridded soil physical properties (e.g., soil texture, porosity) were taken from the World Inventory of Soil Emission Potentials (ISRIC-WISE) spatial soil database (Batjes, 2006). Soil-specific hydraulic properties (e.g., saturated hydraulic conductivity, field capacity) were estimated based on a hydraulic parameter lookup table (Cosby et al., 1984). For the VIC model parameterization, vegetation-specific parameters (e.g., minimum stomatal resistance, rooting depths) were obtained from the VIC model website (http://www.hydro.washington.edu/ Lettenmaier/Models/VIC/), and typical calibration parameters that control soil water infiltration processes were taken from previous studies (Nijssen et al., 2001a, b, c). For the
TEM model parameterization, key parameters that control methanogenesis and methanotrophy processes were taken from Zhuang et al. (2004).

\subsection{TOPMODEL parameterization}

In the VIC-TEM-TOPMODEL framework, the redistribution of WTD was made by applying topography-based watershed-scale TOPMODEL to represent spatial variability of local WTD. By assuming uniform soil hydraulic properties within each watershed and that local transmissivity decreases exponentially with depth (Beven and Kirkby, 1979), the relationship between local WTD $\left(Z_{\mathrm{wt}_{i}}\right)$ and watershedmean water table $\left(\overline{Z_{\mathrm{wt}}}\right)$ was expressed as

$Z_{\mathrm{wt}_{i}}=\overline{Z_{\mathrm{wt}}}-\left(\mathrm{TWI}_{i}-\overline{\mathrm{TWI}}\right) \times m$

where $\mathrm{TWI}_{i}$ represents local topographic wetness index, and $\overline{T W I}$ represents watershed-mean TWI. The watershed-mean water table $\left(\overline{Z_{\mathrm{wt}}}\right)$ was calculated as an area-weighted mean WTD of intersected VIC grid cells (Figs. S1 and S2). $m$ is a decay parameter controlling the exponential decline of transmissivity with depth, and a larger $m$ corresponds to deeper soil (slower declining rate of transmissivity with depth) and therefore stronger spatial variance of the local WTD $\left(Z_{\mathrm{wt}_{i}}\right)$ within a watershed. The magnitude of $m$ is determined by the local sediment-bedrock profile, which is controlled by climate and geology/topography. Following Fan and MiguezMacho (2011), the following equation was used to represent the effects of climate and topography on the parameter $m$ 

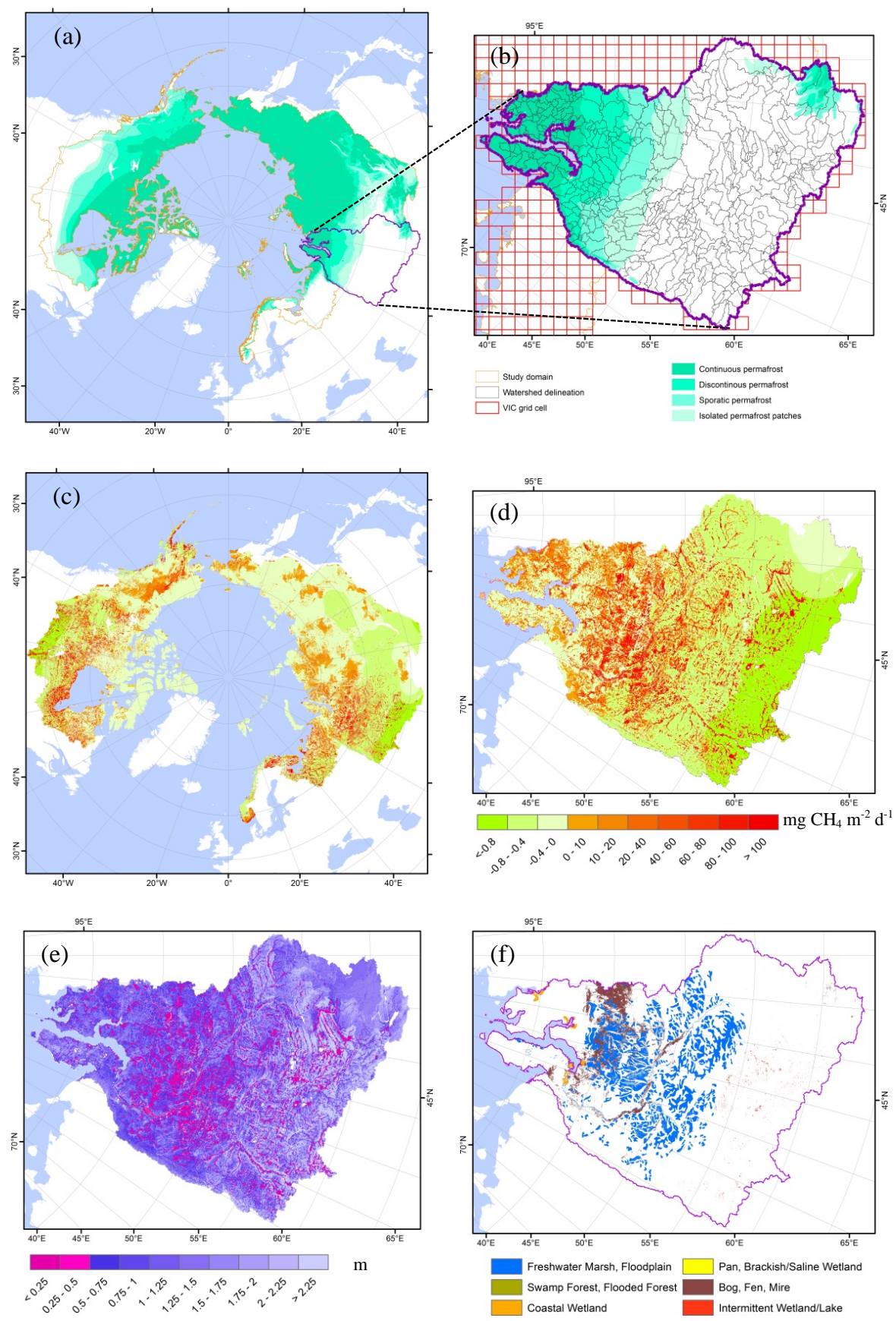

Fig. 2. The study domain, the pan-Arctic, overlaid with the distribution of permafrost (a), example sub-region (West Siberian Lowlands) with watershed delineation and VIC grid cells (b), mean daily methane fluxes (c and d) and water table depth (e) during the growing season (May-September) at a $5 \mathrm{~km}$ spatial resolution, and cartography-based GLWD wetland data (f) (Lehner and Döll, 2004).

over the pan-Arctic:

$m=\frac{\alpha \times f_{T}}{1+150 \times s}$

$f_{T}= \begin{cases}0.17+0.005 \times T & \left(T<-14{ }^{\circ} \mathrm{C}, f_{T} \geq 0.05\right) \\ 1.5+0.1 \times T & \left(-14{ }^{\circ} \mathrm{C} \leq T \leq-5^{\circ} \mathrm{C}\right) \\ 1 & \left(T \geq-5^{\circ} \mathrm{C}\right)\end{cases}$ where $s$ is local terrain slope; $f_{T}$ is a temperature piecewise function used to represent the effect of frozen soil on soil drainage depth, in which $T$ is mean surface air temperature in January; and $\alpha$ is a calibration parameter.

For each month of the period 1993-2004, a three-step calibration procedure was used to best match the monthly TOPMODEL-based spatially averaged fraction of inundated 
area to the monthly satellite-based inundation fraction, derived from the Global Inundation Extent from Multi-Satellite data set (GIEMS) (Prigent et al., 2007; Papa et al., 2010), over the pan-Arctic: (1) the spatially averaged fraction of inundated area $\left(A_{i}\right)$ in a month was first calculated from GIEMS data; (2) the parameter $\alpha$ was calibrated to find an optimal value for that month to generate monthly-mean $Z_{\mathrm{wt}_{i}}$ having a probability of $P\left(Z_{\mathrm{wt}_{i}} \leq 0\right)=A_{i}$; and then (3) the optimal $\alpha$ was applied to each day in that month to calculate daily $Z_{\mathrm{wt}_{i}}$. The daily $Z_{\mathrm{wt}_{i}}$ was set as zero whenever it was negative (above the soil surface) in the simulation of $\mathrm{CH}_{4}$ emissions. An illustration of TOPMODEL parameterization, description of topography-related spatial data, and calibration results were provided in supplementary materials.

\subsection{Simulation protocol}

In this study, two sets of model simulations, with (referred to as VIC-TEM-TOPMODEL simulation) and without (referred to as VIC-TEM simulation) considering sub-grid spatial variability of WTD, were conducted to estimate daily $\mathrm{CH}_{4}$ emissions. In the first set of simulations, we used the VIC-TEM-TOPMODEL framework to simulate daily $\mathrm{CH}_{4}$ fluxes: VIC and TEM were operated at a spatial resolution of 100 and $5 \mathrm{~km}$, respectively, and the simulated $100 \mathrm{~km}$ grid-cell-mean WTD was redistributed into $5 \mathrm{~km}$ WTD at a sub-grid level via a TOPMODEL-based parameterization scheme. The choice of $5 \mathrm{~km}$ here was a special case of a finer spatial resolution for the VIC-TEM-TOPMODEL simulations, but the choice of any finer spatial resolution should not affect our comparison when the TOPMODEL-based parameterization scheme was applied. The probability distributions of $100 \mathrm{~km}$ and $5 \mathrm{~km}$ WTD over the region shared the same mean value but with distinct variances. The variance of WTD increased after the redistribution of WTD, and the degree of the increase was determined by the parameter calibration ( $m$ in Eq. 2) with a target of best matching the simulated monthly inundated area fraction to GIEMS data. Thus, the variance of WTD at a finer spatial resolution was only determined by satellite-based saturated area fraction; and the probability distribution of WTD at a finer scale did not change no matter what finer resolution was used. In the second set of simulations, only VIC and TEM models were used. In this case, both VIC and TEM were operated at the same spatial resolution $(100 \mathrm{~km})$ and no redistribution of WTD was applied. Due to the limited availability of GIEMS data used for the TOPMODEL-based parameterization scheme, these two sets of model simulations were run from 1993 to 2004. The VIC-TEM-TOPMODEL simulations at a $5 \mathrm{~km}$ spatial resolution were used to analyze the spatial and temporal dynamics of $\mathrm{CH}_{4}$ emissions over the pan-Arctic. The effects of spatial scale-dependent WTD on $\mathrm{CH}_{4}$ emissions were examined by comparing the $100 \mathrm{~km}$ and $5 \mathrm{~km} \mathrm{CH}_{4}$ simulations with VICTEM-TOPMODEL and VIC-TEM models, respectively.

\section{Results}

\subsection{Comparison between model simulations and observations}

To evaluate the performance of our model simulations, we compared our estimates of WTD and $\mathrm{CH}_{4}$ fluxes with site observations over the pan-Arctic. The estimated WTD was compared with a data set of water table observations at wells, compiled by Fan et al. (2013). The comparison was limited to those well sites with a shallow water table $(<2 \mathrm{~m}$ below the land surface, $\sim 5000$ sites across southern Canada) where surface soil moisture is possibly coupled to water table (Fan et al., 2007). Given the observation uncertainty in water table data (only one record of a static water table is available at most wells; Fan et al., 2013) and the influences of human activities (e.g., pumping, irrigation, and drainage) that were not represented in large-scale models, we can only realistically compare the overall trend of WTD. The observations of WTD were grouped into 10 bins with a $20 \mathrm{~cm}$ interval and then compared to simulated mean WTD over the growing season (May-September). The comparison indicated that simulated $5 \mathrm{~km}$ WTD was able to track the overall trend of WTD observations and performed better than simulated $100 \mathrm{~km}$ WTD (Fig. 3c), which appeared to show a moderate water table fluctuation without tracking shallower or deeper water tables (Fig. 3a). Although the WTD simulations were improved at a $5 \mathrm{~km}$ spatial resolution, the wide spread of simulated WTD within each observation group (Fig. 3b) indicated that $5 \mathrm{~km}$ WTD still cannot simulate water table dynamics well on a pixel-by-pixel basis.

The $\mathrm{CH}_{4}$ fluxes at 22 field observation sites over the panArctic (Table S1, most in the West Siberian Lowlands (WSL, Fig. 2b)) were used in our comparison. The comparison of the simulated and observed mean daily $\mathrm{CH}_{4}$ fluxes over the growing season indicated that our $5 \mathrm{~km}$ simulations were able to mimic the mean states of site $\mathrm{CH}_{4}$ fluxes and performed much better than $100 \mathrm{~km} \mathrm{CH}_{4}$ simulations that underestimated $\mathrm{CH}_{4}$ fluxes to a large extent (Fig. 3d). To further evaluate our $5 \mathrm{~km}$ simulations, we compared our estimates with airborne-based investigations of regional-scale $\mathrm{CH}_{4}$ emissions from the Hudson Bay Lowlands (HBL). Using airborne eddy covariance techniques, Roulet et al. (1994) made a regional $\mathrm{CH}_{4}$ emission estimate of $0.5 \pm 0.2 \mathrm{Tg} \mathrm{CH}_{4} \mathrm{yr}^{-1}$ from the $\mathrm{HBL}\left(50^{\circ} \mathrm{N}-60^{\circ} \mathrm{N}, 75^{\circ} \mathrm{W}-96^{\circ} \mathrm{W}\right)$ in 1990 . Our estimate of corresponding area, $3.1 \pm 0.5 \mathrm{Tg} \mathrm{CH}_{4} \mathrm{yr}^{-1}$ from 1993 to 2004, was much higher than the estimate of Roulet et al. (1994), but comparable to more recent estimates ( $2.3 \pm 0.3 \mathrm{Tg} \mathrm{CH}_{4} \mathrm{yr}^{-1}$ from 2004 to 2008) of Pickett-Heaps et al. (2011), who quantified $\mathrm{CH}_{4}$ emissions by using the GEOS-Chem chemical transport model over the HBL. 

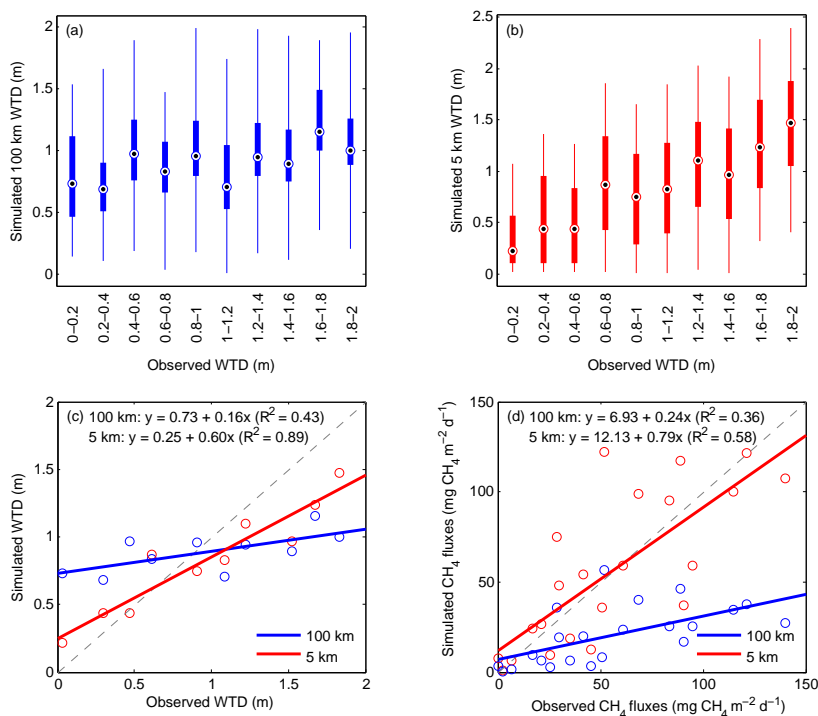

Fig. 3. Comparison of the observed and simulated water table depth (WTD, a-c) and daily methane fluxes (d) during the growing season (May-September). Observed WTD at well sites $(\sim 5000$ sites across southern Canada), with shallow water tables $(<2 \mathrm{~m}$ below the land surface), are retrieved from Fan et al. (2013). Observed WTD are grouped into 10 bins with a $20 \mathrm{~cm}$ interval and then compared to the simulated WTD at $100 \mathrm{~km}$ (a) and $5 \mathrm{~km}$ (b) spatial resolutions (boxes represent $50 \%$ of the data, with median values indicated by circles and the whiskers representing the minimum and maximum), with fitted lines of median values also shown (c). The observations of methane fluxes are derived from 22 field sites over the pan-Arctic (Table S1).

\subsection{Spatial patterns of methane fluxes}

The $5 \mathrm{~km}$ simulations indicated that there was a large spatial variability of land-atmospheric $\mathrm{CH}_{4}$ fluxes over the panArctic (Fig. 2c). The highest emissions of $\mathrm{CH}_{4}$ occurred in the WSL and the HBL, where extensive wetlands exist, with a source of atmospheric $\mathrm{CH}_{4}$ up to $400 \mathrm{mg} \mathrm{CH}_{4} \mathrm{~m}^{-2} \mathrm{~d}^{-1}$ during the growing season. The sinks of atmospheric $\mathrm{CH}_{4}$ occurred in the southern parts of Canada and Siberia, where drier ecosystems with higher soil temperatures favor $\mathrm{CH}_{4}$ consumption, with a sink up to $1.5 \mathrm{mg} \mathrm{CH}_{4} \mathrm{~m}^{-2} \mathrm{~d}^{-1}$. The overall spatial variations of $\mathrm{CH}_{4}$ fluxes over the pan-Arctic were consistent with previous emission estimations (e.g., Zhuang et al., 2004; Petrescu et al., 2010; Melton et al., 2013), most of which featured the WSL and the HBL as high emission regions.

To analyze the relationship between $5 \mathrm{~km} \mathrm{CH}_{4}$ fluxes and major environmental controls, the WSL sub-region was further analyzed. The spatial patterns of $\mathrm{CH}_{4}$ emissions and consumption were dominated by the distribution of WTD, although the spatial patterns were also affected by soil temperatures with a southward increasing trend (Fig. 2d, e). As expected, at a $5 \mathrm{~km}$ spatial resolution, shallower water table positions corresponded to higher $\mathrm{CH}_{4}$ emissions, while deeper water table positions corresponded to lower $\mathrm{CH}_{4}$ emissions and favored $\mathrm{CH}_{4}$ consumption. In addition, positive $\mathrm{CH}_{4}$ fluxes (i.e., net $\mathrm{CH}_{4}$ emissions) generally occurred when the WTD was less than $0.5 \mathrm{~m}$, beyond which soils generally acted as a sink of $\mathrm{CH}_{4}$ (Fig. 2d, e). We also compared the simulated WTD to an existing cartography-based 30 arcsec wetland map (GLWD-3, Lehner and Döll, 2004), and found that the spatial pattern of WTD was generally consistent with the wetland map, although inconsistences existed in the southern part of the WSL (Fig. 2e, f). The depth of $0.5 \mathrm{~m}$ appeared to be a WTD threshold to determine the spatial distribution of wetlands in the WSL, although this threshold was slightly deeper than those thresholds $(0.2-0.4 \mathrm{~m})$ suggested by Fan and Miguez-Macho (2011).

\subsection{Temporal variability of methane fluxes}

Driven with 12-year climate data, the $5 \mathrm{~km}$ simulations showed that the inter-annual variability of $\mathrm{CH}_{4}$ fluxes from terrestrial ecosystems over the pan-Arctic ranged from $38.1 \mathrm{Tg} \mathrm{CH}_{4} \mathrm{yr}^{-1}$ in 2000 to $55.4 \mathrm{Tg} \mathrm{CH}_{4} \mathrm{yr}^{-1}$ in 1994 (Fig. 4a). The estimated annual $\mathrm{CH}_{4}$ emissions were within the range of previous measurements and model-based estimates, ranging from 20 to $157 \mathrm{TgCH}_{4} \mathrm{yr}^{-1}$, with the minimum and maximum values reported by Christensen et al. (1996) and Petrescu et al. (2010), respectively. There was a significant declining trend of annual net $\mathrm{CH}_{4}$ emissions from 1993 to 2004, with an annual decreasing rate of $0.83 \mathrm{Tg} \mathrm{CH}_{4} \mathrm{yr}^{-2}$. Correlation analysis indicated that annual $5 \mathrm{~km} \mathrm{CH} 4$ emissions were inversely correlated with WTD (statistically significant) and soil temperature (statistically insignificant), both of which had an increasing trend during the 12-year period (Fig. 4a, Table 1). The high correlation coefficient $(r=-0.66$, at a significance level of $p<0.05)$ between annual $5 \mathrm{~km} \mathrm{CH}_{4}$ emissions and WTD highlighted the importance of WTD in determining $\mathrm{CH}_{4}$ fluxes.

To examine the seasonal variability of daily $\mathrm{CH}_{4}$ emissions, we took the year 1994, having maximum $5 \mathrm{~km} \mathrm{CH}_{4}$ emissions from 1993 to 2004, as an example year for analysis (Fig. 4b). Most emissions occurred from May to September, with the highest fluxes in July. Low $\mathrm{CH}_{4}$ emissions were estimated in winter due to low soil temperature, while high $\mathrm{CH}_{4}$ emissions occurred in summer due to high soil temperature and a shallow water table. Although both WTD and soil temperature influenced $\mathrm{CH}_{4}$ emissions, the temporal dynamics of daily $\mathrm{CH}_{4}$ fluxes were correlated better with WTD than soil temperature. Daily $\mathrm{CH}_{4}$ emissions and WTD had a consistent seasonal variability with concurrent increases, peaks and decreases. The trough of $\mathrm{CH}_{4}$ fluxes occurring in early August was caused by an abrupt drop of the water table, which could be attributed to the sudden decrease of precipitation but nevertheless high evapotranspiration (indicated by air temperature) in August (Fig. S5). 
Table 1. Pearson correlations between annual $\mathrm{CH}_{4}$ emissions (at $5 \mathrm{~km}$ and $100 \mathrm{~km}$ resolutions) and spatially averaged water table depth and top-layer $(0-5 \mathrm{~cm})$ soil temperature during the growing season (May-September) over the pan-Arctic during the period 1993-2004. The annual changing rate of each variable is given in corresponding brackets.

\begin{tabular}{lrr}
\hline & $\begin{array}{r}\text { Water table depth } \\
\left(0.2 \mathrm{~cm} \mathrm{yr}^{-1}\right)\end{array}$ & $\begin{array}{r}\text { Soil temperature } \\
\left(0.046^{\mathrm{a}}{ }^{\circ} \mathrm{C} \mathrm{yr}^{-1}\right)\end{array}$ \\
\hline $\mathrm{CH}_{4}$ emissions at a $5 \mathrm{~km}$ resolution $\left(-0.83^{\mathrm{a}} \mathrm{Tg} \mathrm{CH}_{4} \mathrm{yr}^{-2}\right)$ & $-0.66^{\mathrm{a}}$ & -0.36 \\
$\mathrm{CH}_{4}$ emissions at a $100 \mathrm{~km}$ resolution $\left(0.74 \mathrm{Tg} \mathrm{CH}_{4} \mathrm{yr}^{-2}\right)$ & -0.15 & $0.84^{\mathrm{b}}$ \\
\hline
\end{tabular}

${ }^{\mathrm{a}} p$ value less than $0.05 .{ }^{\mathrm{b}} p$ value less than 0.01 .
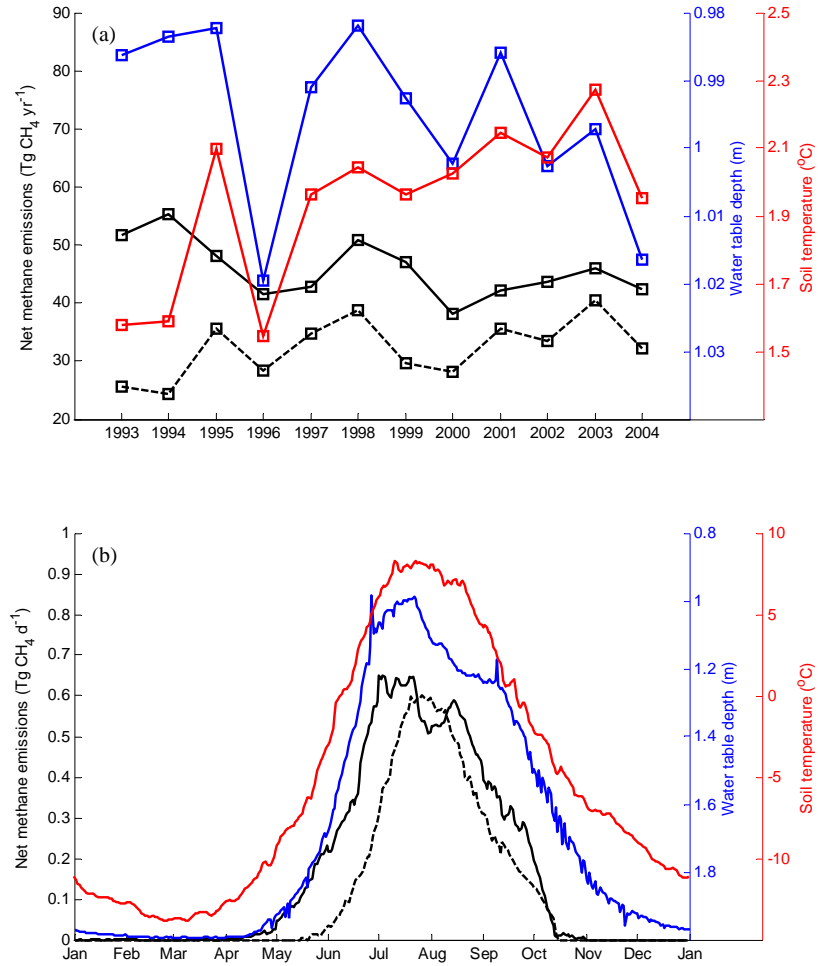

Fig. 4. Inter-annual (a) and seasonal (b) variability of simulated $5 \mathrm{~km}$ net methane emissions over the pan-Arctic and spatially averaged water table depth and top-layer $(0-5 \mathrm{~cm})$ soil temperature. Mean water table depth and soil temperature during the growing season (May-September) are shown for inter-annual variability, and dashed lines represent simulated methane emissions at a $100 \mathrm{~km}$ spatial resolution. The daily simulations of the year 1994, having maximum annual methane emissions at a $5 \mathrm{~km}$ resolution, are shown for the seasonal variability. Note the water table depth has an inverse $y$ axis different from the others.

\subsection{Differences due to spatial scales}

There were large differences in both magnitude and temporal variability of methane emissions between $5 \mathrm{~km}$ and $100 \mathrm{~km}$ simulations. Mean annual net $\mathrm{CH}_{4}$ emissions simulated at a $5 \mathrm{~km}$ resolution ( $45.8 \mathrm{Tg} \mathrm{CH}_{4} \mathrm{yr}^{-1}$ ) from 1993 to 2004 were on average $42 \%$ larger than those simulated at a $100 \mathrm{~km}$ resolution (32.2 $\mathrm{Tg} \mathrm{CH}_{4} \mathrm{yr}^{-1}$ ) (Fig. 4a). The $100 \mathrm{~km} \mathrm{CH}_{4}$ emissions tended to increase from 1993 to 2004 (statistically insignificant), which was contrary to the $5 \mathrm{~km} \mathrm{CH}_{4}$ emissions (Fig. 4a, Table 1). The inter-annual variability of the $100 \mathrm{~km}$ $\mathrm{CH}_{4}$ emissions was positively correlated with soil temperature $(r=0.84$, at a significance level of $p<0.01)$. Similarly, the $100 \mathrm{~km}$ daily $\mathrm{CH}_{4}$ emissions had a consistent temporal variability with daily soil temperature (Fig. 4b). The $100 \mathrm{~km}$ $\mathrm{CH}_{4}$ emissions were more dependent on soil temperature than on WTD, which was the opposite of the $5 \mathrm{~km}$ simulations.

The difference in the magnitude of annual net $\mathrm{CH}_{4}$ emissions between $100 \mathrm{~km}$ and $5 \mathrm{~km}$ resolutions was due to changing emitting area and flux density. One the one hand, the fraction of $\mathrm{CH}_{4}$-emitting area at a $5 \mathrm{~km}$ resolution was higher than that at a $100 \mathrm{~km}$ resolution due to the enhanced variance of WTD after WTD redistribution (19\% vs. $12 \%$ over the WSL, Fig. 5), although spatially averaged WTD was same. On the other hand, mean flux density of $5 \mathrm{~km}$ simulations over all emitting grid cells was larger than that of $100 \mathrm{~km}$ resolution due to the nonlinear dependence of $\mathrm{CH}_{4}$ emissions on WTD (Fig. 5). As such, the increases in both emitting area and $\mathrm{CH}_{4}$ flux density resulted in a $42 \%$ increase of annual net $\mathrm{CH}_{4}$ emissions over the study region. The annual total $\mathrm{CH}_{4}$ budget at a $5 \mathrm{~km}$ resolution was consistently larger during the period 1993-2004. In addition, the differences in $\mathrm{CH}_{4}$ emissions at these two scales varied across the region. Positive bias of $\mathrm{CH}_{4}$ emissions (higher at a $5 \mathrm{~km}$ resolution) between the two scales tended to occur in those grid cells with deeper water tables, while negative bias tended to occur in those with shallower water tables (Fig. 6). This was consistent with the findings in Bohn and Lettenmaier (2010) that the simulated daily $\mathrm{CH}_{4}$ fluxes without considering the sub-grid spatial heterogeneity of WTD (100 km simulation in our case) had biased high (low) under shallower (deeper) water table conditions.

In TEM, the emission rates of $\mathrm{CH}_{4}$ have a positive temperature response and a negative WTD response (higher $\mathrm{CH}_{4}$ emissions at shallower water tables) (Zhuang et al., 2004). Our simulations showed that WTD was influenced by temperature (deeper water table resulting from enhanced evapotranspiration at higher temperature), as indicated by the opposite inter-annual trends between water table and soil temperature (Fig. 4a). Thus, the relative importance of soil 

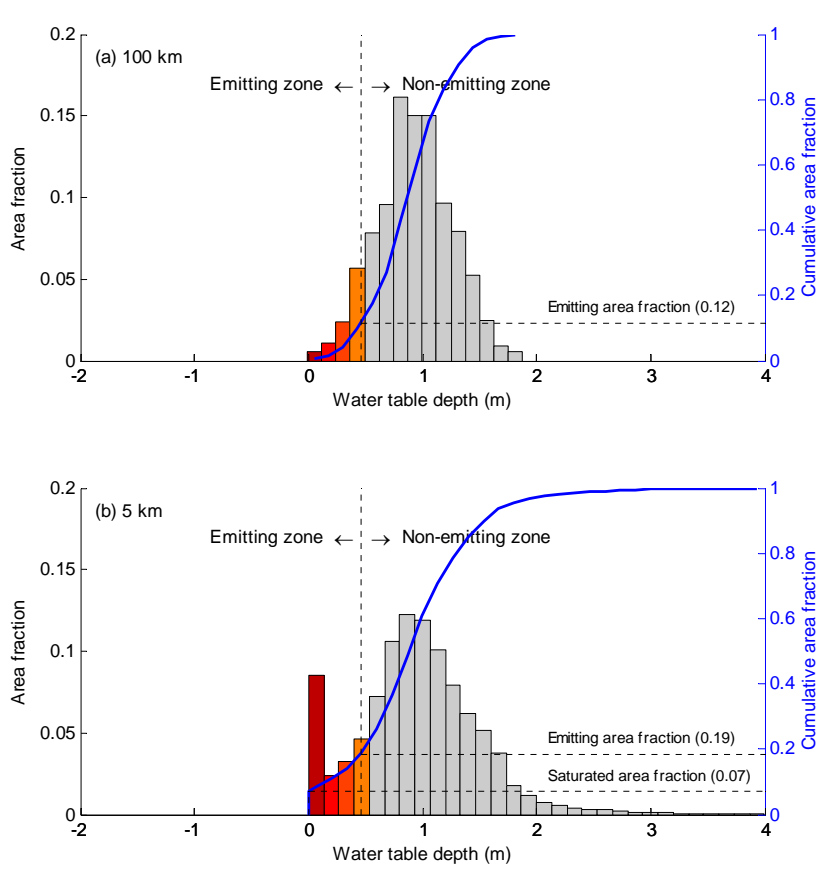

Fig. 5. Probability distributions of mean water table depth during the growing season (May-September) at $100 \mathrm{~km}$ (a) and $5 \mathrm{~km}$ (b) spatial resolutions across West Siberian Lowlands. The colored and grey bars indicate methane-emitting and non-emitting zones, respectively; darker colored bars correspond to higher methaneemitting rates.

temperature and WTD on $\mathrm{CH}_{4}$ emissions depended on their relative intensity and their interactions. According to the nonlinear dependence of $\mathrm{CH}_{4}$ on WTD, the range of WTD could be conceptually divided into two emitting zones (Fig. 5): low-sensitivity zone (light-colored bars) and high-sensitivity zone (dark-colored bars). At a $100 \mathrm{~km}$ resolution (Fig. 5a), more emitting grid cells belonged to low-sensitivity zone, and thus the WTD had a relatively small influence on $\mathrm{CH}_{4}$ emissions. On the contrary, at a $5 \mathrm{~km}$ resolution (Fig. 5b), more emitting grid cells belonged to the high-sensitivity zone, and WTD became a dominant controlling factor (as shown in Fig. 2d, e).

\section{Discussion}

The higher $5 \mathrm{~km} \mathrm{CH}_{4}$ emissions result from the wider distribution of $5 \mathrm{~km} \mathrm{WTD}$, the degree of which is controlled by the decaying parameter ( $m$ in Eq. 2 ) used in the TOPMODEL parameterization scheme. The accuracy of estimated $5 \mathrm{~km}$ WTD depends on how well the VIC model simulates $100 \mathrm{~km}$ WTD and how reliable the TOPMODEL-based downscaling $(100 \mathrm{~km}$ to $5 \mathrm{~km}$ WTD) process is. Both of these are greatly influenced by how we characterize soil hydraulic properties. One the one hand, in our simulations of $100 \mathrm{~km}$ WTD, grid-cell-mean soil hydraulic parameterizations were derived
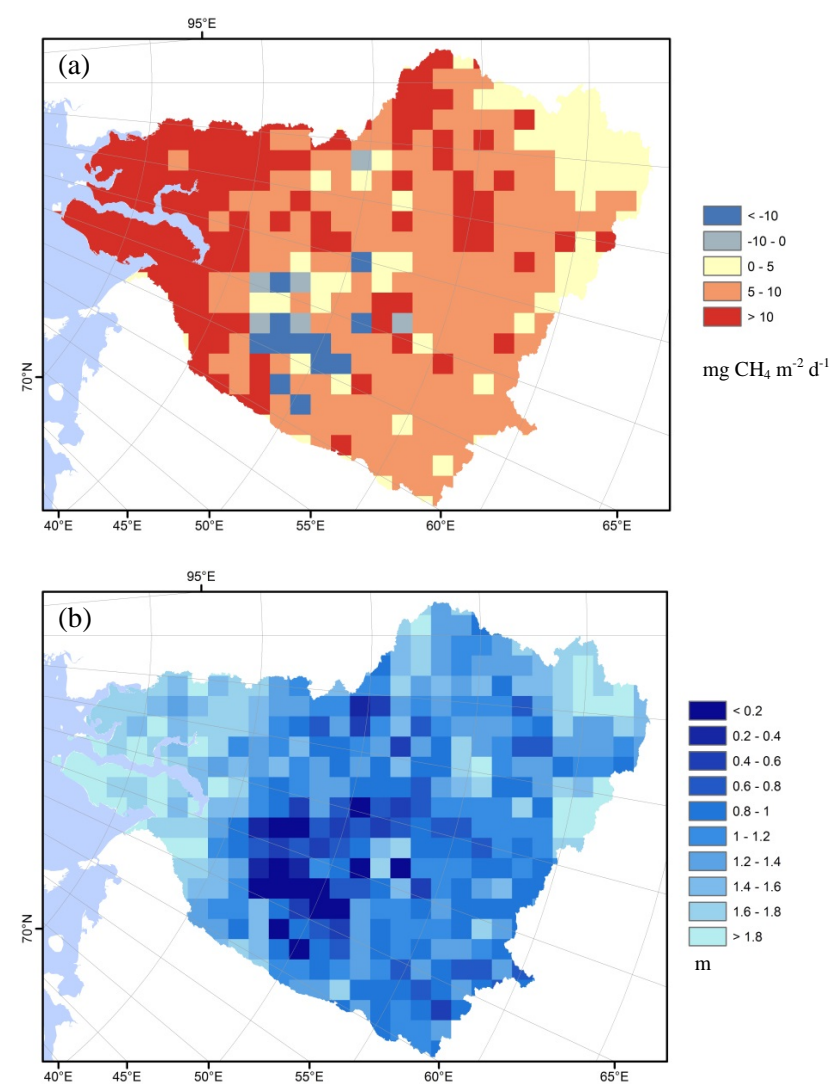

Fig. 6. The difference in mean methane fluxes between $5 \mathrm{~km}$ and $100 \mathrm{~km}$ simulations (a), and simulated $100 \mathrm{~km}$ mean water table depth (b), during the growing season (May-September) across the West Siberian Lowlands.

from a hydraulic parameter look-up table for mineral soils (Cosby et al., 1984), based on grid-cell-mean soil textures (Batjes, 2006). We did not explicitly consider organic soils, which exist in those grid cells with partial wetland coverage. Thus, without incorporating the information of organic soils, our model could simulate higher values and stronger seasonality of water tables (and therefore $\mathrm{CH}_{4}$ emissions) at a $100 \mathrm{~km}$ spatial resolution, given that organic soils in wetlands have substantially different hydraulic properties from mineral soils (e.g., larger porosity and permeability) (Letts et al., 2000). One the other hand, we assumed uniform soil hydraulic properties across a watershed in the TOPMODEL downscaling process. This assumption is necessary for the TOPMODEL algorithm (Beven, 1997), but assuming homogeneous soils over a heterogeneous watershed (a mix of wetlands and uplands) could also result in shallower simulated water tables and greater seasonal fluctuation (at a $5 \mathrm{~km} \mathrm{spa-}$ tial resolution) in wetland soils (major $\mathrm{CH}_{4}$-emitting zones) within the watershed, as well as opposite biases in upland soils (minor $\mathrm{CH}_{4}$-emitting zones) within the watershed. Although these error sources could be compensated to get "unbiased" $5 \mathrm{~km}$ WTD by the calibration of parameter $\alpha$ (Eq. 3) 
during the TOPMODEL downscaling process, they may influence the accurate comparison of WTD and therefore $\mathrm{CH}_{4}$ emissions between the two spatial resolutions. Further assessment of these error sources should be conducted in future study.

Another error source associated with the TOPMODEL parameterization scheme is that we exclude any negative WTD (water table above the soil surface) in the simulations of $5 \mathrm{~km}$ $\mathrm{CH}_{4}$ emissions, since water column oxidation of $\mathrm{CH}_{4}$ is not represented in TEM. The exclusion of standing water oxidation may, to a certain degree, affect the quantification of the difference in $\mathrm{CH}_{4}$ emissions between $100 \mathrm{~km}$ and $5 \mathrm{~km}$ simulations, but it should not substantially contribute to the difference. Take the histogram of $5 \mathrm{~km}$ WTD of the WSL (Fig. 5b) as an example; around $7 \%$ of land area is covered by standing water. If we use a porosity of 0.5 (mean value over the pan-Arctic) to calculate the amount of excessive water and water column height, more than two-thirds of these inundated areas (negative WTD) will have a water table of $20 \mathrm{~cm}$ or less above soil surface. According to a synthesis study of $\mathrm{CH}_{4}$ emissions across northern permafrost zones (Olefeldt et al., 2013), $\mathrm{CH}_{4}$ emissions with a water table of 0-20 cm above soil surface are comparable to, if not larger than, emission fluxes with a water table at soil surface (Fig. 2d in Olefeldt et al., 2013).

Compared to site observations of $\mathrm{CH}_{4}$ fluxes, our $5 \mathrm{~km}$ $\mathrm{CH}_{4}$ simulations performed much better than $100 \mathrm{~km} \mathrm{CH}$ simulations and were able to generally track the mean states of $\mathrm{CH}_{4}$ fluxes. However, substantial differences between observations and simulations still exist. This might be partially caused by the difference in spatial scales between observations and simulations. Our $5 \mathrm{~km}$ model simulations represent mean states of water table and $\mathrm{CH}_{4}$ emissions over the grid cell $\left(25 \mathrm{~km}^{2}\right)$, while site observations of water table and $\mathrm{CH}_{4}$ fluxes typically represent mean states of different measurement locations within a much smaller area. Field studies have found extremely high spatial variations of $\mathrm{CH}_{4}$ emission rates, even under similar environmental conditions (e.g., Van Huissteden et al., 2005). The spatial heterogeneity of $\mathrm{CH}_{4}$ fluxes in wetlands might be greatly controlled by local surface patterns or microtopography (e.g., hummocks and hollows), which plays a critical role in determining local WTD (Eppinga et al., 2008; Glagolev et al., 2011). For example, Eppinga et al. (2008) found that the difference in WTD between hummocks and hollows was almost equal to the difference in local elevation (on the order of 50-70 cm). In our TOPMODEL-based model framework, we did not incorporate the effects of microtopography on WTD and therefore $\mathrm{CH}_{4}$ fluxes, since this type of microtopography (on the scale of meters) cannot be captured by large-scale DEMs (on the scale of kilometers). Thus, given the nonlinear dependence of $\mathrm{CH}_{4}$ emissions on water tables, our estimates of $5 \mathrm{~km} \mathrm{CH}$ fluxes may not exactly represent $\mathrm{CH}_{4}$ emissions. A microtopography-based model framework (e.g., Bohn et al., 2013) could be a better model framework, if not limited by the availability of microtopography information, to improve the simulations of spatial variations of water table and $\mathrm{CH}_{4}$ emissions, especially for extremely flat areas where TOPMODEL-based methods might not be valid since WTD are more related to local elevation rather than slope. However, for our model applications over the pan-Arctic, detailed microtopography information is not available for most regions and only large-scale DEM data is available for characterizing topography. In future study, the optimal WTD downscaling scheme for large-scale applications could be a combination of TOPMODEL-based and microtopography-based schemes, in which both large-scale DEM data and available small-scale microtopography information can be incorporated.

The difference in regional $\mathrm{CH}_{4}$ emissions between the two spatial resolutions implies that previous large-scale biogeochemical model applications using a grid-cell-mean WTD scheme might have underestimated contemporary $\mathrm{CH}_{4}$ budget in the northern high latitudes. Although the magnitude of the increase in $\mathrm{CH}_{4}$ emissions could be model-dependent, any large-scale model estimates of high-latitude $\mathrm{CH}_{4}$ emissions should benefit from incorporating sub-grid WTD spatial heterogeneity. Our findings are also relevant to the projection studies of high-latitude $\mathrm{CH}_{4}$ emissions. Although the projections of larger high-latitude $\mathrm{CH}_{4}$ emissions are expected by incorporating sub-grid WTD dynamics, we cannot equate the bias from historical simulations to that from projection simulations. The amount of the bias in projection simulations may be greatly determined by the changing trend of future water tables, which is in turn determined by future climate change. A larger bias may occur if future climate becomes wetter since rising water tables promote more emissions at $5 \mathrm{~km}$ simulations compared with $100 \mathrm{~km}$ simulations $\left(\mathrm{CH}_{4}\right.$ emission rate increases exponentially with rising water tables), while a smaller bias may occur if future climate becomes drier. Furthermore, by incorporating sub-grid WTD spatial heterogeneity, there will be greater sensitivity of $\mathrm{CH}_{4}$ emissions to WTD since a larger fraction of area belongs to high-sensitive zones in $5 \mathrm{~km}$ simulations (Fig. 5), which highlights the importance of sub-grid water table dynamics in the projections of future $\mathrm{CH}_{4}$ emissions. Current model projections of high-latitude $\mathrm{CH}_{4}$ emissions focus more on the effects of climate warming and resultant permafrost thawing (e.g., Koven et al., 2011). However, our historical simulations indicate that high-latitude $\mathrm{CH}_{4}$ emissions are more related with WTD, if sub-grid water table dynamics are considered, than soil temperature. Although our historical simulations cannot be used to conclude the relative importance of WTD and soil temperature in future high-latitude $\mathrm{CH}_{4}$ emissions, the effects of sub-grid WTD spatial heterogeneity should be included in the projections of future high-latitude $\mathrm{CH}_{4}$ emissions. 


\section{Conclusions}

Using a coupled hydrology-biogeochemistry model, two sets of simulations at two different spatial resolutions (100 and $5 \mathrm{~km}$ ) were conducted to explore the effects of sub-grid spatial variability of water table dynamics on $\mathrm{CH}_{4}$ emissions over the pan-Arctic. The results suggest that previous macroscale biogeochemical models using grid-cell-mean water table depth might have underestimated the regional $\mathrm{CH}_{4}$ emissions. This study further indicates that the inter-annual variability of regional $\mathrm{CH}_{4}$ emissions is also spatial-scale dependent. Overall, the sub-grid spatial variability of water table depth should be considered in order to adequately simulate $\mathrm{CH}_{4}$ emissions in the northern high latitudes.

\section{Supplementary material related to this article is available online at http://www.biogeosciences.net/11/ 1693/2014/bg-11-1693-2014-supplement.zip.}

\begin{abstract}
Acknowledgements. The research is funded by a DOE SciDAC project and an Abrupt Climate Change project. This study is also supported through projects funded by the NASA Land Use and Land Cover Change program (NASA-NNX09AI26G), Department of Energy (DE-FG02-08ER64599), the NSF Division of Information \& Intelligent Systems (NSF-1028291), and the NSF Carbon and Water in the Earth Program (NSF-0630319). This research is also in part supported by the Director, Office of Science, Office of Biological and Environmental Research of the US Department of Energy under Contract No. DE-AC02-05CH11231 as part of their Earth System Modeling Program.
\end{abstract}

Edited by: D. Obrist

\section{References}

Batjes, N. H.: ISRIC-WISE derived soil properties on a 5 by 5 arcminutes global grid (version 1.0), Wageningen: ISRIC - World Soil Information, 2006.

Beven, K.: TOPMODEL: a critique, Hydrol. Process., 11, 10691085, 1997.

Beven, K. J. and Kirkby, M. J.: A physically based, variable contributing area model of basin hydrology, Hydrolog. Sci. Bull., 24, 43-69, doi:10.1080/02626667909491834, 1979.

Bohn, T. J. and Lettenmaier, D. P.: Systematic biases in largescale estimates of wetland methane emissions arising from water table formulations, Geophys. Res. Lett., 37, L22401, doi:10.1029/2010g1045450, 2010.

Bohn, T. J., Lettenmaier, D. P., Sathulur, K., Bowling, L. C., Podest, E., McDonald, K. C., and Friborg, T.: Methane emissions from western Siberian wetlands: heterogeneity and sensitivity to climate change, Environ. Res. Lett., 2, 045015, doi:10.1088/17489326/2/4/045015, 2007.

Bohn, T. J., Podest, E., Schroeder, R., Pinto, N., McDonald, K. C., Glagolev, M., Filippov, I., Maksyutov, S., Heimann, M.,
Chen, X., and Lettenmaier, D. P.: Modeling the large-scale effects of surface moisture heterogeneity on wetland carbon fluxes in the West Siberian Lowland, Biogeosciences, 10, 6559-6576, doi:10.5194/bg-10-6559-2013, 2013.

Chen, Y. H. and Prinn, R. G.: Estimation of atmospheric methane emissions between 1996 and 2001 using a three-dimensional global chemical transport model, J. Geophys. Res, 111, 1-25, 2006.

Cherkauer, K. A., Bowling, L. C., and Lettenmaier, D. P.: Variable infiltration capacity cold land process model updates, Global Planet. Change, 38, 151-159, 2003.

Christensen, T. R., Prentice, I. C., Kaplan, J., Haxeltine, A., and Sitch, S.: Methane flux from northern wetlands and tundra, Tellus B, 48, 652-661, 1996.

Christensen, T. R., Ekberg, A., Strom, L., Mastepanov, M., Panikov, N., Oquist, M., Svensson, B. H., Nykanen, H., Martikainen, P. J., and Oskarsson, H.: Factors controlling large scale variations in methane emissions from wetlands, Geophys. Res. Lett., 30, 1414, doi:10.1029/2002GL016848, 2003.

Cosby, B. J., Hornberger, G. M., Clapp, R. B., and Ginn, T. R.: A statistical exploration of the relationships of soil moisture characteristics to the physical properties of soils, Water Resour. Res., 20, 682-690, doi:10.1029/WR020i006p00682, 1984.

Eppinga, M. B., Rietkerk, M., Borren, W., Lapshina, E. D., Bleuten, W., and Wassen, M. J.: Regular surface patterning of peatlands: confronting theory with field data, Ecosystems, 11, 520-536, 2008.

Fan, Y. and Miguez-Macho, G.: A simple hydrologic framework for simulating wetlands in climate and earth system models, Clim. Dynam., 37, 253-278, doi:10.1007/s00382-010-0829-8, 2011.

Fan, Y., Miguez-Macho, G., Weaver, C. P., Walko, R., and Robock, A.: Incorporating water table dynamics in climate modeling: 1. Water table observations and equilibrium water table simulations, J. Geophys. Res., 112, D10125, doi:10.1029/2006JD008111, 2007.

Fan, Y., Li, H., and Miguez-Macho, G.: Global Patterns of Groundwater Table Depth, Science, 339, 940-943, 2013.

Gao, X., Schlosser, C. A., Sokolov, A., Anthony, K. W., Zhuang, Q., and Kicklighter, D.: Permafrost degradation and methane: low risk of biogeochemical climate-warming feedback, Environ. Res. Lett., 8, 035014, doi:10.1088/1748-9326/8/3/035014, 2013.

Glagolev, M., Kleptsova, I., Filippov, I., Maksyutov, S., and Machida, T.: Regional methane emission from West Siberia mire landscapes, Environ. Res. Lett., 6, 045214, doi:10.1088/17489326/6/4/045214, 2011.

Gracia, C. A., Tello, E., Sabaté, S., and Bellot, J.: GOTILWA: An integrated model of water dynamics and forest growth, in: Ecology of Mediterranean evergreen oak forests, Springer, 163-179, 1999.

Heikkinen, J. E. P., Elsakov, V., and Martikainen, P. J.: Carbon dioxide and methane dynamics and annual carbon balance in tundra wetland in NE Europe, Russia, Global Biogeochem. Cy., 16, 1115, doi:10.1029/2002gb001930, 2002.

Hunt, E. R. and Running, S. W.: Simulated dry matter yields for aspen and spruce stands in the North American boreal forest, Can. J. Remote Sens., 18, 126-133, 1992.

Kim, H. S., Maksyutov, S., Glagolev, M. V., Machida, T., Patra, P. K., Sudo, K., and Inoue, G.: Evaluation of methane emissions from West Siberian wetlands based on inverse modeling, Env- 
iron. Res. Lett., 6, 035201, doi:10.1088/1748-9326/6/3/035201, 2011.

Koven, C. D., Ringeval, B., Friedlingstein, P., Ciais, P., Cadule, P., Khvorostyanov, D., Krinner, G., and Tarnocai, C.: Permafrost carbon-climate feedbacks accelerate global warming, P. Natl. Acad. Sci. USA, 108, 14769-14774, 2011.

Lammers, R. B., Shiklomanov, A. I., Vörösmarty, C. J., Fekete, B. M., and Peterson, B. J.: Assessment of contemporary Arctic river runoff based on observational discharge records, J. Geophys. Res., 106, 3321-3334, doi:10.1029/2000JD900444, 2001.

Lehner, B. and Döll, P.: Development and validation of a global database of lakes, reservoirs and wetlands, J. Hydrol., 296, 1-22, doi:10.1016/j.jhydrol.2004.03.028, 2004.

Letts, M. G., Roulet, N. T., Comer, N. T., Skarupa, M. R., and Verseghy, D. L.: Parametrization of peatland hydraulic properties for the Canadian Land Surface Scheme, Atmos. Ocean, 38, 141-160, 2000

Levy, P. E., Cannell, M. G. R., and Friend, A. D.: Modelling the impact of future changes in climate, $\mathrm{CO}_{2}$ concentration and land use on natural ecosystems and the terrestrial carbon sink, Global Environ. Change, 14, 21-30, 2004.

Liang, X., Lettenmaier, D. P., Wood, E. F., and Burges, S. J.: A simple hydrologically based model of land surface water and energy fluxes for general circu-lation models, J. Geophys. Res, 99, 14415-14428, 1994

Lu, X. and Zhuang, Q.: Modeling methane emissions from the Alaskan Yukon River basin, 1986-2005, by coupling a largescale hydrological model and a process-based methane model, J. Geophys. Res., 117, G02010, doi:10.1029/2011jg001843, 2012.

MacDonald, J. A., Fowler, D., Hargreaves, K. J., Skiba, U., Leith, I. D., and Murray, M. B.: Methane emission rates from a northern wetland; response to temperature, water table and transport, Atmos. Environ., 32, 3219-3227, 1998.

McGuire, A. D., Hayes, D. J., Kicklighter, D. W., Manizza, M., Zhuang, Q., Chen, M., Follows, M. J., Gurney, K. R., McClelland, J. W., Melillo, J. M., Peterson, B. J., and Prinn, R. G.: An analysis of the carbon balance of the Arctic Basin from 1997 to 2006, Tellus B, 62, 455-474, doi:10.1111/j.16000889.2010.00497.x, 2010.

Melton, J. R., Wania, R., Hodson, E. L., Poulter, B., Ringeval, B., Spahni, R., Bohn, T., Avis, C. A., Beerling, D. J., Chen, G., Eliseev, A. V., Denisov, S. N., Hopcroft, P. O., Lettenmaier, D. P., Riley, W. J., Singarayer, J. S., Subin, Z. M., Tian, H., Zürcher, S., Brovkin, V., van Bodegom, P. M., Kleinen, T., Yu, Z. C., and Kaplan, J. O.: Present state of global wetland extent and wetland methane modelling: conclusions from a model intercomparison project (WETCHIMP), Biogeosciences, 10, 753788, doi:10.5194/bg-10-753-2013, 2013.

Nijssen, B., O'Donnell, G. M., Hamlet, A. F., and Lettenmaier, D. P.: Hydrologic sensitivity of global rivers to climate change, Climatic Change, 50, 143-175, 2001a

Nijssen, B., O’Donnell, G. M., Lettenmaier, D. P., Lohmann, D., and Wood, E. F.: Predicting the discharge of global rivers, J. Climate, 14, 3307-3323, 2001b.

Nijssen, B., Schnur, R., and Lettenmaier, D. P.: Global Retrospective Estimation of Soil Moisture Using the Variable Infiltration Capacity Land Surface Model, 1980-93, J. Climate, 14, 1790$1808,2001 \mathrm{c}$.
Nykänen, H., Alm, J., Silvola, J., Tolonen, K., and Martikainen, P J.: Methane fluxes on boreal peatlands of different fertility and the effect of long-term experimental lowering of the water table on flux rates, Global Biogeochem. Cy., 12, 53-69, 1998.

Olefeldt, D., Turetsky, M. R., Crill, P. M., and McGuire, A D.: Environmental and physical controls on northern terrestrial methane emissions across permafrost zones, Global Change Biol., 19, 589-603, 2013.

Papa, F., Prigent, C., Aires, F., Jimenez, C., Rossow, W. B., and Matthews, E.: Interannual variability of surface water extent at the global scale, 1993-2004, J. Geophys. Res, 115, D12111, doi:10.1029/2009JD012674, 2010.

Petrescu, A. M. R., van Huissteden, J., Jackowicz-Korczynski, M., Yurova, A., Christensen, T. R., Crill, P. M., Bäckstrand, K., and Maximov, T. C.: Modelling $\mathrm{CH} 4$ emissions from arctic wetlands: effects of hydrological parameterization, Biogeosciences, 5, 111-121, doi:10.5194/bg-5-111-2008, 2008

Petrescu, A. M. R., van Beek, L. P. H., van Huissteden, J., Prigent, C., Sachs, T., Corradi, C. A. R., Parmentier, F. J. W., and Dolman, A. J.: Modeling regional to global $\mathrm{CH}_{4}$ emissions of boreal and arctic wetlands, Global Biogeochem. Cy., 24, GB4009, doi:10.1029/2009gb003610, 2010.

Pickett-Heaps, C. A., Jacob, D. J., Wecht, K. J., Kort, E. A., Wofsy, S. C., Diskin, G. S., Worthy, D. E. J., Kaplan, J. O., Bey, I., and Drevet, J.: Magnitude and seasonality of wetland methane emissions from the Hudson Bay Lowlands (Canada), Atmos. Chem. Phys., 11, 3773-3779, doi:10.5194/acp-11-3773-2011, 2011.

Prigent, C., Papa, F., Aires, F., Rossow, W. B., and Matthews, E.: Global inundation dynamics inferred from multiple satellite observations, 1993-2000, J. Geophys. Res, 112, D12107, doi:10.1029/2006JD007847, 2007.

Roulet, N. T., Jano, A., Kelly, C. A., Klinger, L. F., Moore, T. R., Protz, R., Ritter, J. A., and Rouse, W. R.: Role of the Hudson Bay lowland as a source of atmospheric methane, J. Geophys. Res., 99, 1439-1454, doi:10.1029/93JD00261, 1994.

Solomon, S., Qin, D., Manning, M., Chen, Z., Marquis, M., Averyt, K. B., Tignor, M., and Miller, H. L.: Climate change 2007: the physical science basis: working Group I contribution to the fourth assessment report of the IPCC, Cambridge University Press, Cambridge, UK and New York, NY, USA, 2007.

Su, F., Adam, J. C., Bowling, L. C., and Lettenmaier, D. P.: Streamflow simulations of the terrestrial Arctic domain, J. Geophys. Res., 110, D08112, doi:10.1029/2004JD005518, 2005.

Su, F., Adam, J. C., Trenberth, K. E., and Lettenmaier, D. P.: Evaluation of surface water fluxes of the pan-Arctic land region with a land surface model and ERA-40 reanalysis, J. Geophys. Res, 111, D05110, doi:10.1029/2005JD006387, 2006.

Van Huissteden, J., Maximov, T. C., and Dolman, A. J.: High methane flux from an arctic floodplain (Indigirka lowlands, eastern Siberia), J. Geophys. Res., 110, G02002, doi:10.1029/2005JG000010, 2005.

Wagner, D., Lipski, A., Embacher, A., and Gattinger, A.: Methane fluxes in permafrost habitats of the Lena Delta: effects of microbial community structure and organic matter quality, Environ. Microbiol., 7, 1582-1592, 2005.

Walter, B. P., Heimann, M., and Matthews, E.: Modeling modern methane emissions from natural wetlands 1 . Model description and results, J. Geophys. Res., 106, 34189-34134, 2001. 
Wania, R., Ross, I., and Prentice, I. C.: Implementation and evaluation of a new methane model within a dynamic global vegetation model: LPJ-WHyMe v1.3.1, Geosci. Model Dev., 3, 565-584, doi:10.5194/gmd-3-565-2010, 2010.

Whalen, S. C. and Reeburgh, W. S.: Moisture and temperature sensitivity of $\mathrm{CH}_{4}$ oxidation in boreal soils, Soil Biol. Biochem., 28, 1271-1281, 1996.

Zhu, X., Zhuang, Q., Chen, M., Sirin, A., Melillo, J., Kicklighter, D., Sokolov, A., and Song, L.: Rising methane emissions in response to climate change in Northern Eurasia during the 21st century, Environ. Res. Lett., 6, 045211, doi:10.1088/17489326/6/4/045211, 2011.

Zhu, X., Zhuang, Q., Gao, X., Sokolov, A., and Schlosser, C. A.: Pan-Arctic land-atmospheric fluxes of methane and carbon dioxide in response to climate change over the 21 st century, Environ. Res. Lett., 8, 045003, doi:10.1088/1748-9326/8/4/045003, 2013a.

Zhu, X., Zhuang, Q., Qin, Z., Glagolev, M., and Song, L.: Estimating wetland methane emissions from the northern high latitudes from 1990 to 2009 using artificial neural networks, Global Biogeochem. Cy., 27, 592-604, doi:10.1002/gbc.20052, 2013 b.
Zhuang, Q., McGuire, A. D., O'Neill, K. P., Harden, J. W., Romanovsky, V. E., and Yarie, J.: Modeling soil thermal and carbon dynamics of a fire chronosequence in interior Alaska, J. Geophys. Res., 107, 8147, doi:10.1029/2001jd001244, 2002.

Zhuang, Q., Melillo, J. M., Kicklighter, D. W., Prinn, R. G., McGuire, A. D., Steudler, P. A., Felzer, B. S., and $\mathrm{Hu}$, S.: Methane fluxes between terrestrial ecosystems and the atmosphere at northern high latitudes during the past century: A retrospective analysis with a process-based biogeochemistry model, Global Biogeochem. Cy., 18, GB3010, doi:10.1029/2004gb002239, 2004.

Zhuang, Q., Melillo, J. M., McGuire, A. D., Kicklighter, D. W., Prinn, R. G., Steudler, P. A., Felzer, B. S., and Hu, S.: Net emissions of $\mathrm{CH}_{4}$ and $\mathrm{CO}_{2}$ in Alaska: implications for the region's greenhouse gas budget, Ecol. Appl., 17, 203-212, 2007. 